\title{
Pengaruh Kepercayaan dan Promosi terhadap Minat UMKM Mengambil Pembiayaan Perbankan Syariah di Kota Langsa
}

\author{
Zikriatul Ulya \\ Program Studi Perbankan Syariah, Fakultas Ekonomi dan Bisnis Islam, \\ IAIN Langsa \\ Meurandeh, Kota Langsa, Provinsi Aceh, Kode Pos 24354 \\ Email: zikriatululya@iainlangsa.ac.id
}

\begin{abstract}
ABSTRAK
Penelitian ini bertujuan atau bermaksud memberikan dampak untuk mengetahui pengaruh kepercayaan dan promosi terhadap minat UMKM dalam mengambil pembiayaan perbankan syariah di Kota Langsa. Metode yang digunakan yaitu deskriptif kuantitatif. Penelitian ini menggunakan teknik probability sampling dengan cara cluster sampling. Sampel yang digunakan adalah pelaku Usaha Mikro, pelaku usaha Kecil dan pelaku usaha Menengah (UMKM) Kota Langsa sebanyak 100 responden. Teknik pengumpulan data menggunakan angket kuesioner dengan membagikan kepada UMKM Kota Langsa. Metode analisis data menggunakan regresi linear berganda. Hasil penelitian uji t menunjukkan bahwa kepercayaan dan promosi secara parsial berpengaruh positif dan signifikan terhadap minat UMKM mengambil pembiayaan perbankan syariah di Kota Langsa. Hasil penelitian uji F menunjukkan bahwa kepercayaan dan promosi berpengaruh positif dan signifikan secara simultan terhadap minat UMKM mengambil pembiayaan perbankan syariah di Kota Langsa. Kesimpulan dari penelitian ini berdasarkan analisis koefisiensi determinasi (adjusted $\mathrm{R}^{2)}$ bahwa 50,1\% variasi nilai minat UMKM mengambil pembiayaan perbankan syariah di Kota Langsa ditentukan oleh dua variabel yang berpengaruh yaitu kepercayaan dan promosi. Sedangkan sisanya 49,9\% dijelaskan oleh variabel lain yang tidak dimasukkan dalam persamaan tersebut diatas.
\end{abstract}

Kata Kunci: Kepercayaan; Promosi; dan Pembiayaan.

\begin{abstract}
The purpose of this research is to examine the effect of trust and promotion toward UMKM interest taking islamic banking financing in the city of Langsa. The method used is the quantitative approach. This study uses probability sampling by cluster sampling. The sample used is a small and medium-size micro business in Langsa city of 100 respondents. The data-collection technique a questionnaire by distributing to the small and medium-size microbusiness of Langsa city. Data analysis methods using linear regression, classic assumptions test, and hypothetical test ( $t$ and test $f$ ). Test $t$-test results have shown that each independent variable of trust and promotion is partially positive and significant. The results of research on the $f$ show that there is a positive and significant impact together between the trust variables and the promotion of the interest of umkm, which is financing sharia banking in the city of Langsa. Based on the results of the study, it is based on coefficiency analysis, that 50,1\% of the disproportionate value of the people, should be satisfied by the two influential variables, trust and promotion. The remaining 49,9\% is described by other variables not included in the equation.
\end{abstract}

Keyword: Trust; Promotion; Financing 


\section{PENDAHULUAN}

Usaha mikro, usaha kecil, dan usaha menengah (UMKM) memiliki peranan yang penting dalam pertumbuhan perekonomian. UMKM merupakan kegiatan atau aktivitas usaha yang berdampakt menambah tenaga kerja serta untuk dapat memperluas atau membuka lapangan kerja salah satu sektor usaha yang menjadi tulang punggung perekonomian nasional. Perannya yang signifikan untuk dapat membuka lapangan menjadikan UMKM sangat efektif sebagai peranti memperkuat stabilitas nasional.

Perkembangan UMKM secara kuantitas dari tahun ke tahun terus meningkat, namun UMKM Dalam mengembangkan usahanya, UMKM dihadapkan pada beberapa permasalahan. Selain dari SDM yang minim, kurangnya sarana dan prasarana, dan teknologi merupakan bagian utama yang dapat menghambat perkembangan UMKM adalah kurangnya modal dan minimnya akses pembiayaan. Modal usaha paling signifikan untuk perusahaan, perusahaan yang belum mempunyai kecukupan modal usaha dapat sulit untuk menjalankan kegiatan usahanya. Pada saat pembiayaan dari bank memiliki kesulitan dikarenakan tingkat suku bunga kredit yang tinggi serta berlakunya adanya jaminan agunan (collateral minded) dalam memperoleh kredit yang sulit untuk pelaku usaha dalam memenuhi syarat-syarat tersebut. Tanpa modal usaha yang memadai perusahaan akan kehilangan kesempatan meningkatkan kuantitas serta kualitas produk yang diproduksi.

Bank syariah memiliki salah satu produk yang dapat membantu mengambil pembiayaan dengan sistem bagi hasil yang dikembangkan dalam produk pembiayaan mudharabah selain perbankan konvensional, sehingga UMKM tidak hanya berpacu pada satu atau dua pilihan pembiayaan saja. Perkembangan dan kemajuan pada sektor keuangan, baik bank maupun lembaga keuangan bukan bank perlu dipertahankan. Dalam aspek kelembagaan, organisasi, regulasi (kebijakan), dan sumber daya manusia (SDM) perlu adanya peningkatan dan perbaikan, khususnya pada lembaga keuangan bukan bank. Bank syariah memiliki core product pembiayaan bagi hasil yang dikembangkan dalam produk pembiayaan musyarakah dan mudharabah. Dengan demikian, keberadaan bank syariah harus mampu memberikan konstribusi untuk meningkatkan pertumbuhan sektor rill seperti sektor UMKM .Semakin berkembangnya bank syariah berimplikasi pada semakin besarnya tantangan yang harus dihadapi bank syariah, dimana tantangan terbesar adalah untuk mempertahankan citra dan nama baik dimata nasabah agar tetap menjaga kepecayaan serta loyalitas nasabah kepada bank syariah.

Kepercayaan adalah keyakinan seseorang terhadap reliabilitas, durabilitas, dan integritas terhadap pihak lain dalam relationship dan keyakinan bahwa tindakannya 
merupakan kepentingan yang paling baik dan akan menghasilkan hasil positif bagi pihak yang dipercaya. Kepercayaan dipandang sebagai unsur mendasar bagi keberhasilan suatu kemitraan. Namun, berdasarkan hasil wawancara disimpulkan bahwa 8 dari 10 pelaku UMKM Kota Langsa memiliki tingkat kepercayaan yang cenderung rendah atau keraguan akan komitmen terhadap perbankan syariah. Pelaku UMKM memiliki keraguan akan konsistensi penerapan prinsip-prinsip syariah dalam operasional maupun produk-produk perbankan syariah, bahkan beberapa pelaku UMKM memiliki persepsi negatif atas praktik perbankan syariah yang hampir sama dengan perbankan konvensional. Hal ini juga didukung oleh hasil penelitian dari Bank Indonesia yang menyatakan bahwa nasabah yang menggunakan jasa bank syariah sebagian memiliki kecenderungan untuk berhenti menjadi nasabah dengan alasan karena keraguan akan komitmen penerapan prinsip syariah. Hal tersebut menunjukkan bahwa selama ini bank syariah tersebut kurang menjalankan prinsipprinsip syariah yang menjadi salah satu yang dapat mempengaruhi kepercayaan masyarakat terhadap perbankan syariah.

Selain itu, agar nasabah berminat untuk mengajukan pembiayaan, maka bank harus memberi pelayanan atau menjalin komunikasi yang baik kepada nasabah. Untuk bisa melakukan komunikasi secara efektif antara bank dengan nasabah maka bank harus mempunyai program-program unggulan seperti promosi yang menarik, mampu memberikan informasi yang akurat kepada nasabah serta mampu menarik nasabah untuk mencari informasi tambahan seputar pesan yang disampaikan oleh perbankan.

Menurut Lamb, Hair dan Mc Daniel (2001), promosi adalah komunikasi dari para penjual yang menginformasikan, membujuk, dan mengingatkan para calon pembeli suatu produk dalam rangka memengaruhi pandangan mereka atau memperoleh suatu tanggapan. Berdasarkan hasil wawancara terhadap 10 pelaku UMKM di Kota Langsa, disimpulkan bahwa promosi yang dilakukan oleh perbankan syariah belum secara maksimal tersampaikan kepada masyarakat khususnya kepada pelaku UMKM sehingga masih banyak pelaku usaha yang belum memahami benar atas produk-produk pembiayaan perbankan syariah, mekanisme dan sistem perbankan syariah.

Berdasarkan pemaparan diatas, penelitian ini bermaksud untuk melihat kecenderungan masyarakat mengetahui pengaruh kepercayaan dan promosi terhadap minat UMKM mengambil pembiayaan perbankan syariah. 


\section{Pengertian Kepercayaan}

Menurut Lawang (2004) kepercayaan adalah hubungan keyakinan antara dua belah pihak atau lebih yang mengandung harapan yang menguntungkan salah satu pihak atau kedua belah pihak melalui interaksi sosial termasuk dalam hubungan ini adalah institusi.

\section{Indikator Kepercayaan}

Menurut Tan dalam Alifiulahtin Utaminingsih (2014), ada beberapa yang menjadi indikator kepercayaan adalah sebagai berikut.

1. Reliabilitas adalah kehandalan atau kemampuan perusahaan untuk memberikan pelayanan sesuai yang dijanjikan secara konsisten dan terpercaya.

2. Perhatian adalah pemusatan pada suatuobjek dengan mengetahui kebutuhan konsumen.

3. Integritas adalah kejujuran perusahaan dalam menawarkan produk yang sesuai dengan informasi yang diberikan perusahaan kepada konsumennya.

\section{Pengertian Promosi}

Menurut Zimmerer (2002), promosi adalah segala macam bentuk komunikasi persuasi yang dirancang untuk menginformasikan pelanggan tentang produk atau jasa dan untuk memengaruhi mereka supaya membeli barang atau jasa tersebut yang meliputi publisitas, penjualan perorangan dan periklanan.

\section{Indikator Promosi}

Ada beberapa yang menjadi indikator promosi adalah sebagai berikut:

1. Periklanan, yaitu bentuk presentasi dari promosi nonpribadi tentang ide jasa perbankan yang dibayar oleh sponsor tertentu.

2. Penjualan pribadi, yaitu suatu dialog dan presentasi secara langsung kepada satu calon nasabah atau lebih yang bertujuan untuk menggunakan jasa bank..

3. Publisitas, yaitu permintaan secara nonpribadi untuk suatu produk jasa perbankan dengan menggunakan berita komersial dalam media massa dan sponsor.

4. Promosi penjualan, yaitu alat motivasi nasabah dimana nasabah tertarik menggunakan jasa bank seperti pemberian insentif kepada nasabah.

\section{Perbankan Syariah}

Perbankan syariah itu sendiri adalah bank yang menjalankan kegiatan usahanya berdasarkan prinsip syariah. Menurut Undang-Undang RI Nomor 21 Tahun 2008 tentang perbankan syariah, perbankan syariah adalah segala sesuatu yang menyangkut tentang Bank Syariah dan Unit Usaha Syariah, mencangkup kelembagaan, kegiatan usaha, serta cara dan proses dalam melaksanakan kegiatan usahanya. 


\section{Pembiayaan}

Pembiayaan adalah suatu dana yang diberikan oleh suatu pihak kepada pihak lain untuk suatu kepentingan usaha atau investasi seseorang dengan maksud mempunyai manfaat yang besar atau pemberian fasilitas penyediaan dana untuk memenuhi kebutuhan pihak-pihak yang merupakan deficit unit. Akad yang digunakan oleh produk-produk pembiayaan ini sebagian besar menggunakan akad mudharabah, musyarakah dan murabahah.

Akad salam digunakan untuk pembiayaan pertanian, sedangkan istishna digunakan untuk pembiayaan pemesanan barang-barang manufaktur.

\section{Usaha Mikro Kecil dan Menengah (UMKM)}

Berdasarkan Undang-Undang Republik Indonesia Nomor 20 Tahun 2008 tentang Usaha Mikro, Kecil dan Menengah (UMKM), UMKM didefinisikan sebagai berikut.

1. Usaha mikro adalah usaha produktif milik orang perorangan dan/atau badan usaha perorangan yang memenuhi kriteria sebagai berikut. Memilik kekayaan bersih paling banyak Rp 50.000.000,00 (lima puluh juta rupiah) tidak termasuk tanah dan bangunan tempat usaha; atau Memiliki hasil penjualan tahunan paling banyak Rp 300.000.000,00 (tiga ratus juta rupiah).

2. Usaha kecil adalah kegiatan ekonomi rakyat yang berskala kecil, dan memenuhi kekayaan bersih atau hasil penjualan tahunan yang bukan merupakan anak perusahaan atau bukan cabang perusahaan, dan Memiliki kekayaan bersih lebih dari Rp 50.000.000,00 (lima puluh juta rupiah) sampai dengan paling banyak Rp 500.000.000,00 (lima ratus juta rupiah) tidak termasuk tanah dan bangunan tempat usaha; atau Memiliki hasil penjualan tahunan lebih dari Rp 300.000.000,00 (tiga ratus juta rupiah) sampai dengan paling banyak Rp 2.500.000.000,00 (dua milyar lima ratus juta rupiah).

3. Usaha menengah merupakan suatu usaha dalam ekonomi yang produktif dan bukan cabang dari usaha utama atau perusahaan pusat serta menjadi bagian secara tidak langsung maupun secara langsung bagi usaha kecil dan atau usaha besar. Memiliki kekayaan bersih lebih dari Rp 500.000.000,00 (lima ratus juta rupiah) sampai dengan paling banyak Rp 10.000.000.000,00 (sepuluh milyar rupiah) tidak termasuk tanah dan bangunan tepat usaha; atau Memiliki hasil penjualan tahunan lebih dari $\mathrm{Rp}$ 2.500.000.000,00 (dua milyar lima ratus juta rupiah) sampai dengan paling banyak Rp 50.00.000.000,00 (lima puluh milyar rupiah). 


\section{Hipotesis}

Hipotesis dalam penelitian ini adalah:

1. Pengaruh kepercayaan terhadap minat UMKM mengambil pembiayaan perbankan syariah di Kota Langsa.

$\mathrm{H}_{01}$ : Kepercayaan tidak berpengaruh positif dan signifikan terhadap minat UMKM mengambil pembiayaan perbankan syariah di Kota Langsa.

$\mathrm{H}_{\mathrm{a} 1}$ : Kepercayaan berpengaruh positif dan signifikan terhadap minat UMKM mengambil pembiayaan pada perbankan syariah di Kota Langsa.

2. Pengaruh promosi terhadap minat UMKM mengambil pembiayaan perbankan syariah di Kota Langsa.

$\mathrm{H}_{02}$ : Promosi tidak berpengaruh positif dan signifikan terhadap minat UMKM mengambil pembiayaan perbankan syariah di Kota Langsa.

$\mathrm{H}_{\mathrm{a} 2}$ : $\quad$ Promosi berpengaruh positif dan signifikan terhadap minat UMKM mengambil pembiayaan pada perbankan syariah di Kota Langsa.

3. Pengaruh kepercayaan dan promosi terhadap minat UMKM mengambil pembiayaan perbankan syariah di Kota Langsa.

$\mathrm{H}_{03}$ : Kepercayaan dan promosi secara bersama-sama tidak berpengaruh positif dan signifikan terhadap minat UMKM mengambil pembiayaan perbankan syariah di Kota Langsa.

$\mathrm{H}_{\mathrm{a} 3}$ : Kepercayaan dan promosi secara bersama-sama berpengaruh positif dan signifikan terhadap minat UMKM untuk mengambil pembiayaan pada Perbankan Syariah di Kota Langsa.

\section{METODE PENELITIAN}

Tempat penelitian ini pada UMKM di Kota Langsa. Waktu penelitian dilakukan pada tanggal 1 November 2019 s/d selesai. Populasi dalam penelitian ini adalah pelaku dari Usaha Mikro Kecil Menengah (UMKM) yang ada di Kota Langsa yang berjumlah 10.946 pelaku usaha (Disperindagkop dan UKM Kota Langsa). Penentuan sampel dalam penelitian ini menggunakan metode probability sampling, yaitu teknik pengambilan sampel dimana seluruh anggota atau elemen populasi memiliki peluang yang sama untuk dijadikan sebagai sampel. Teknik yang digunakan pada penelitian ini adalah cluster sampling, yaitu cara pengambilan sampel dengan memilih klaster-klaster atau area-area tertentu secara random untuk setiap unit sampling. Untuk menentukan jumlah sampel dari suatu populasi dapat menggunakan cara dengan rumus Slovin, yaitu: 


$$
n=\frac{\mathrm{N}}{1+\mathrm{Ne}^{2}}
$$

Dimana:

$\mathrm{n}=$ Ukuran Sampel

$\mathrm{N}=$ Ukuran Populasi

$\mathrm{e}=$ persen kelonggaran

Persen kelonggaran penelitian ini diasumsikan sebesar 10\%, sehingga ukuran sampel dapat dihitung sebagai berikut:

$$
n=\frac{10.946}{1+10.946(0,1)^{2}}=\frac{10.946}{110,46}=99,094
$$

Dengan demikian ukuran sampel pada penelitian ini adalah 99,094 dibulatkan menjadi 100 sampel.

Tabel 1. Sampel Data Penelitian

\begin{tabular}{clcc}
\hline No & Kriteria UMKM & Populasi & Sampel \\
\hline 1 & Usaha Mikro & 3.989 & 37 \\
2 & Usaha Kecil & 465 & 4 \\
3 & Usaha Menengah & 6.492 & 59 \\
& Jumlah & $\mathbf{1 0 . 9 4 6}$ & $\mathbf{1 0 0}$ \\
\hline
\end{tabular}

Sumber: Data diolah

Metode analisis data yang digunakan dalam penelitian ini adalah analisis regresi linier berganda. Adapun model matematis dari analisis regresi linier berganda dalam penelitian ini adalah sebagai berikut:

$$
\mathbf{Y}=\mathbf{a}+\mathbf{b}_{1} \mathbf{X}_{1}+\mathbf{b}_{2} \mathbf{X}_{2}+\mathbf{e}
$$

Dimana:

$\mathrm{Y}=$ Minat pembiayaan

$\mathrm{a}=$ Bilangan konstanta

$\mathrm{X}_{1}=$ Kepercayaan

$\mathrm{X}_{2}=$ Promosi

$b_{1}, b_{2}=$ koefisien regresi untuk masing-masing variabel independen

$\mathrm{e}=$ eror

Pengujian hipotesis dalam penelitian ini adalah sebagai berikut:

1. Uji t (uji parsial)

Pengujian parsial digunakan untuk membuktikan apakah terdapat pengaruh antara kepercayaan $\left(\mathrm{X}_{1}\right)$, dan promosi $\left(\mathrm{X}_{2}\right)$ terhadap minat mengambil pembiayaan $(\mathrm{Y})$ 
2. Uji F (Uji simultan)

Pengujian simultan (Uji F) digunakan untuk menguji pengaruh secara bersama-sama terdapat pengaruh antara kepercayaan $\left(\mathrm{X}_{1}\right)$, dan promosi $\left(\mathrm{X}_{2}\right)$ terhadap minat mengambil pembiayaan $(\mathrm{Y})$

3. Koefisien Determinasi $\left(\mathrm{R}^{2}\right)$

Koefisien determinasi $\left(\mathrm{R}^{2}\right)$ digunakan untuk menjelaskan proporsi variabel independen (kepercayaan dan promosi) yang mampu menjelaskan variasi variabel dependennya (minat pembiayaan).

\section{HASIL DAN PEMBAHASAN}

\section{Uji Kelayakan Data}

\section{Uji Normalitas}

Pengujian normalitas data dilakukan untuk melihat apakah dalam model regresi, variabel dependen dan independennya memiliki distribusi normal atau tidak.

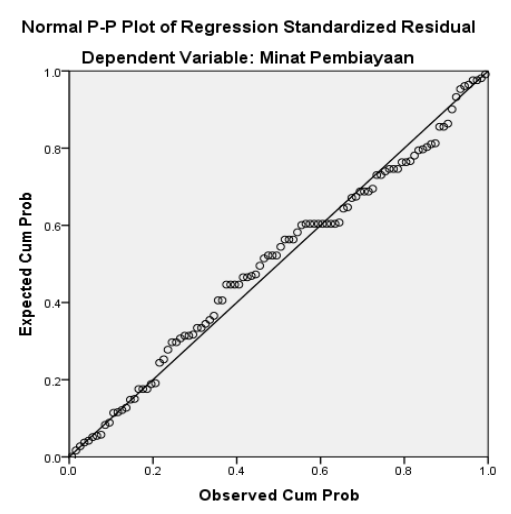

Gambar 1

\section{Kurva Normal P - Plot}

Dengan melihat Gambar 1 diatas Normal P - Plot dapat diketahui bahwa data yang menyebar disepanjang garis diagonal dan mengikuti arah garis diagonal, maka data tersebut berdistribusi normal dan telah memenuhi asumsi normalitas.

\section{Uji Multikolinearitas}

Uji multikolinearitas adalah uji untuk variabel bebas, dimana korelasi antar variabel bebas dilihat. Multikolinearitas dapat diketahui dari nilai Varians Inflaction factor (VIF) dan nilai tolerance. Jika nilai VIF $\leq 10$ dan nilai tolerance $>0,1$ maka dinyatakan tidak terjadi multikolinearitas. 
Tabel 2. Hasil Uji Multikolinieritas

\begin{tabular}{cccc}
\hline Variabel & Tolerance & VIF & KET \\
\hline Kepercayaan $(\mathrm{X} 1)$ & 0,600 & 1,667 & Lolos \\
Promosi $(\mathrm{X} 2)$ & 0,600 & 1,667 & Lolos \\
\hline
\end{tabular}

Sumber: Data Primer diolah, 2020

Dari Tabel 2 diatas Hasil uji multikolinearitas pada menunjukkan bahwa nilai tolerance variabel Kepercayaan dan Promosi yaitu 0,600 > 0,1. Sementara itu nilai VIF variabel Kepercayaan dan Promosi yaitu 1,667 < 10. Dapat diambil kesimpulan bahwa variabel Kepercayaan dan Promosi tidak mengandung multikolinearitas. Artinya tidak terjadi korelasi antar variabel independen.

\section{Uji Heterokedastisitas}

Dalam pengambilan keputusannya adalah jika pola tertentu, seperti butir- butir (titiktitik) yang ada membentuk suatu pola tertentu yang teratur, maka terjadi heterokedastisitas. Jika tidak ada pola yang jelas, serta butir- butir (titik - titik) yang menyebar di seputaran angka 0 pada sumbu Y, maka tidak terjadi heterokedastisitas.

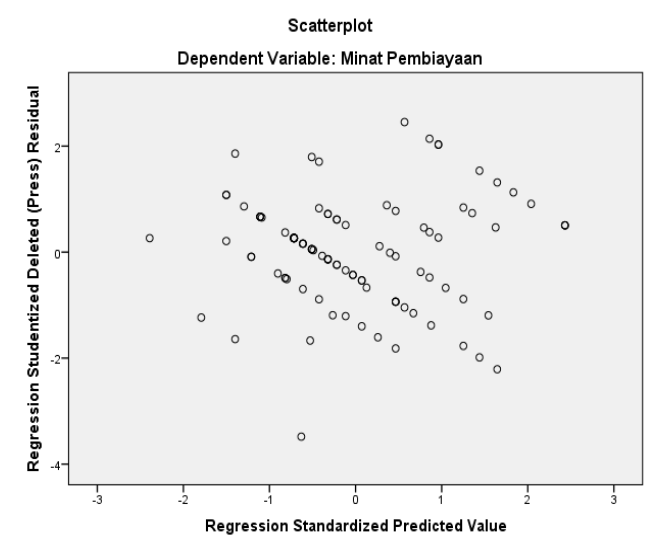

\section{Gambar 2. Hasil Uji Heterokedastisitas}

Berdasarkan Gambar 2 hasil uji heterokedastisitas diatas, terlihat butir-butir (titiktitik) tersebut pada gambar Scattreplot menyebar atau tidak membentuk pola tertentu. Artinya tidak terjadi heteroskedastisitas pada model regresi yang digunakan.

\section{Uji Autokorelasi}

Autokorelasi bertujuan untuk menguji apakah terjadi korelasi antara satu periode $t$ dengan periode sebelumnya (t-1). Jika terjadi korelasi, maka dinamakan ada problem autokorelasi. Model regresi yang baik adalah bebas dari autokorelasi.

Salah satu cara mengindentifikasinya adalah dengan melihat nilai Durbin Watson (DW).Apabila nilai D-W dibawah -2 berarti ada autokorelasi positif. Jika nilai D-W diantara -2 
sampai +2 berarti tidak ada autokorelasi. Jika nilai $\mathrm{D}-\mathrm{W}$ diatas +2 berarti ada autokorelasi negative.

Tabel 3. Hasil Uji Autokorelasi

\section{Model Summary ${ }^{\mathrm{b}}$}

\begin{tabular}{|c|c|c|c|c|c|c|c|c|c|}
\hline \multirow[t]{3}{*}{ Model } & \multirow[t]{3}{*}{$\mathrm{R}$} & \multirow{3}{*}{$\begin{array}{c}\mathrm{R} \\
\text { Square }\end{array}$} & \multirow{3}{*}{$\begin{array}{l}\text { Adjusted } \\
\text { R Square }\end{array}$} & \multirow{3}{*}{$\begin{array}{l}\text { Std. Error } \\
\text { of the } \\
\text { Estimate }\end{array}$} & \multicolumn{4}{|c|}{ Change Statistics } & \multirow{3}{*}{$\begin{array}{l}\text { Durbin- } \\
\text { Watson }\end{array}$} \\
\hline & & & & & $\mathrm{R}$ & $\mathrm{F}$ & df1 df2 & Sig. F & \\
\hline & & & & & $\begin{array}{l}\text { Square } \\
\text { Change }\end{array}$ & Change & & Change & \\
\hline 1 & 15 & .511 & .501 & 1.173 & .511 & 50.717 & 297 & .000 & 1.56 \\
\hline
\end{tabular}

a. Predictors: (Constant), Promosi, Kepercayaan

b. Dependent Variable: Minat Pembiayaan

Sumber: Data Primer diolah pada SPSS 21, 2020

Dari Tabel 3 hasil uji autokorelasi tersebut diperoleh nilai D-W yang dihasilkan dari model regresi adalah 1,568. Maka dapat disimpulkan bahwa nilai D-W berada diantara -2 sampai +2 dengan demikian hasil uji autokorelasi dalam penelitian ini tidak ada autokorelasi. Sehingga asumsi klasik dari penelitian ini terpenuhi.

\section{Uji Linearitas}

Uji linearitas bertujuan untuk mengetahui ada tidaknya hubungan secara linear antara variabel dependen terhadap setiap variabel independen yang hendak diuji. Aturan untuk keputusan linearitas dapat dengan membandingkan nilai signifikan dari deviation from linearity $>0,05$ maka nilai tersebut linear.

Tabel 4. Hasil Uji Linearitas Variabel Kepercayaan ANOVA Table

\begin{tabular}{|c|c|c|c|c|c|c|c|}
\hline & & & $\begin{array}{c}\text { Sum of } \\
\text { Squares }\end{array}$ & $\mathrm{df}$ & $\begin{array}{l}\text { Mean } \\
\text { Square }\end{array}$ & $\mathrm{F}$ & Sig. \\
\hline \multirow{5}{*}{$\begin{array}{l}\text { Minat Pembiayaan * } \\
\text { Kepercayaan }\end{array}$} & \multirow{3}{*}{$\begin{array}{l}\text { Between } \\
\text { Groups }\end{array}$} & (Combined) & 134.357 & 14 & 9.597 & 5.891 & .000 \\
\hline & & Linearity & 88.937 & 1 & 88.937 & 54.589 & .000 \\
\hline & & $\begin{array}{l}\text { Deviation from } \\
\text { Linearity }\end{array}$ & 45.420 & 13 & 3.494 & 2.144 & .119 \\
\hline & \multicolumn{2}{|c|}{ Within Groups } & 138.483 & 85 & 1.629 & & \\
\hline & \multicolumn{2}{|l|}{ Total } & 272.840 & 99 & & & \\
\hline
\end{tabular}

Sumber: Data Primer diolah pada SPSS 21, 2020

Tabel 5. Hasil Uji Linearitas Variabel Promosi ANOVA Table

\begin{tabular}{|c|c|c|c|c|c|c|c|}
\hline & & & $\begin{array}{l}\text { Sum of } \\
\text { Squares }\end{array}$ & $\mathrm{df}$ & $\begin{array}{c}\text { Mean } \\
\text { Square }\end{array}$ & $\mathrm{F}$ & Sig. \\
\hline \multirow{5}{*}{$\begin{array}{l}\text { Minat Pembiayaan * } \\
\text { Promosi }\end{array}$} & & \multirow{3}{*}{$\begin{array}{l}\text { (Combined) } \\
\text { Linearity } \\
\text { Deviation from } \\
\text { Linearity }\end{array}$} & 155.819 & 12 & 12.985 & 9.654 & .000 \\
\hline & Between & & 131.577 & 1 & 131.577 & 97.822 & .000 \\
\hline & Groups & & 24.242 & 11 & 2.204 & 1.638 & .102 \\
\hline & Within G & & 117.021 & 87 & 1.345 & & \\
\hline & Total & & 272.840 & 99 & & & \\
\hline
\end{tabular}

Sumber: Data Primer diolah pada SPSS 21, 2020 
Berdasarkan Tabel 4 dan Tabel 5 hasil uji linearitas menunjukkan nilai koefisien signifikasi dari variabel kepercayaan sebesar 0,119 danvariabel promosi sebesar 0,102 yang artinya lebih besar dari alpha yang ditentukan, yaitu $0,05(0,102>0,05)$. Ini berarti bahwa hubungan kedua variabel independen tersebut dengan variabel dependen adalah linear.

Dari hasil perhitungan SPSS, didapati hasil regresi sebagai berikut:

Tabel 6. Hasil Uji Regresi Linear Berganda

Coefficients $^{\mathbf{a}}$

\begin{tabular}{|c|c|c|c|c|c|c|}
\hline \multirow[t]{2}{*}{ Model } & & \multicolumn{2}{|c|}{$\begin{array}{c}\text { Unstandardized } \\
\text { Coefficients }\end{array}$} & $\begin{array}{c}\text { Standardized } \\
\text { Coefficients }\end{array}$ & \multirow[t]{2}{*}{$\mathrm{t}$} & \multirow[t]{2}{*}{ Sig. } \\
\hline & & $\mathrm{B}$ & Std. Error & Beta & & \\
\hline \multirow{3}{*}{1} & (Constant) & .750 & 1.582 & & .474 & .636 \\
\hline & Kepercayaan & .122 & .051 & .220 & 2.396 & .019 \\
\hline & Promosi & .345 & .057 & .556 & 6.062 & .000 \\
\hline
\end{tabular}

a. Dependent Variable: Minat Pembiayaan

Sumber: Data Primer diolah pada SPSS 21, 2020

$$
\mathrm{Y}=0,750+0,122+0,345+\mathrm{e}
$$

1. Nilai konstan (Y) sebesar 0,750 jika variabel kepercayaan dan promosi nilainya adalah nol (0), maka variabel minat UMKM mengambil pembiayaan perbankan syariah di Kota Langsa (Y) akan berada pada angka 0,750.

2. Koefisien regresi kepercayaan sebesar 0,122 , artinya jika variabel independen lain nilainya tetap dan kepercayaan mengalami kenaikan 1 satuan maka minat UMKM mengambil pembiayaan perbankan syariah di Kota Langsa juga akan meningkat 0,122 satuan.

3. Koefisien regresi promosi sebesar 0,345 , artinya jika variabel independen lain nilainya tetap dan promosi mengalami kenaikan 1 satuan maka minat UMKM mengambil pembiayaan perbankan syariah di Kota Langsa juga akan meningkat 0,345 satuan.

\section{Uji Hipotesis}

\section{Uji t (Uji Parsial)}

Uji signifikansi secara parsial digunakan untuk melihat pengaruh tiap-tiap variabel independen secara sendiri-sendiri terhadap variabel dependennya. Kriteria pengujiannya apabila nilai signifikasi $<0,05$ dan atau jika $t_{\text {hitung }}>t_{\text {tabel }}$ maka model regresi signifikan secara statistik dan dapat disimpulkan bahwa $\mathrm{H}_{0}$ ditolak.

Berdasarkan tabel 6, maka dapat disimpulkan bahwa:

1. Pengaruh kepercayaan terhadap minat UMKM mengambil pembiayaan perbankan syariah di Kota Langsa.

Nilai variabel kepercayaan $t_{\text {hitung }}$ sebesar 2,396 > 0,1985, dengan nilai signifikasi sebesar $0,019<$ alpha 0,05 maka $\mathrm{H}_{0}$ ditolak. Artinya kepercayaan berpengaruh positif dan 
signifikan terhadap minat UMKM mengambil pembiayaan perbankan syariah dengan demikian hipotesis diterima.

2. Pengaruh promosi terhadap minat UMKM mengambil pembiayaan perbankan syariah di Kota Langsa.

Nilai variabel promosi $t_{\text {hitung }}$ sebesar 6,062>0,1985, dengan nilai signifikasi sebesar $0,000<$ alpha 0,05 maka $\mathrm{H}_{0}$ ditolak. Artinya promosi berpengaruh positif dan signifikan terhadap minat UMKM mengambil pembiayaan perbankan syariah dengan demikian hipotesis diterima.

\section{Uji F (Uji Simultan)}

Uji F pada dasarnya menunjukkan apakah semua variabel bebas (Kepercayaan dan Promosi) yang dimasukkan ke dalam model mempunyai pengaruh secara bersama-sama terhadap variabel terikat (Minat Pembiayaan).

\section{Tabel 7. Hasil Analisis Uji F}

ANOVA ${ }^{\mathrm{a}}$

\begin{tabular}{llrrrrr}
\hline Model & & $\begin{array}{l}\text { Sum of } \\
\text { Squares }\end{array}$ & df & Mean Square & F & Sig. \\
\hline \multirow{3}{*}{1} & Regression & 139.468 & 2 & 69.734 & 50.717 & $.000^{\mathrm{b}}$ \\
& Residual & 133.372 & 97 & 1.375 & & \\
& Total & 272.840 & 99 & & & \\
\hline
\end{tabular}

a. Dependent Variable: Minat Pembiayaan

b. Predictors: (Constant), Promosi, Kepercayaan

Sumber: Data Primer diolah pada SPSS 21, 2020

Berdasarkan Tabel 7 pengujian hipotesis yang menyatakan ada pengaruh secara simultan (keseluruhan) kepercayaan dan promosi terhadap minat UMKM mengambil pembiayaan perbankan syariah di Kota Langsa dapat dilihat dari hasil uji F pada tabel. Nilai $\mathrm{F}_{\text {hitung }}=50,717>\mathrm{F}_{\text {tabel }}$ 3,09 dengan nilai signifikan $=0,000$. Dengan demikian nilai signifikan $(0,000<0,05)$, maka terdapat pengaruh yang signifikan antara Kepercayaan (X1) dan Promosi (X2) terhadap minat UMKM mengambil pembiayaan (Y).

\section{Koefisiensi Determinasi $\left(\mathbf{R}^{2}\right)$}

Tabel 8 menunjukkan nilai adjusted $\mathrm{R}^{2}$ sebesar 0,501 yang berarti bahwa 50,1\% variasi nilai minat UMKM mengambil pembiayaan perbankan syariah ditentukan oleh dua variabel yang berpengaruh yaitu kepercayaan dan promosi. Sedangkan sisanya (100\% - 50,1 $\%=49,9 \%$ ) dijelaskan oleh variabel lain yang tidak dimasukkan dalam persamaan tersebut diatas. 
Tabel 8. Hasil Uji Determinasi $\left(\mathbf{R}^{2}\right)$

Model Summary ${ }^{b}$

\begin{tabular}{|c|c|c|c|c|c|c|c|c|c|}
\hline \multirow[t]{3}{*}{ Model } & \multirow[t]{3}{*}{$\mathrm{R}$} & \multirow{3}{*}{$\begin{array}{c}\mathrm{R} \\
\text { Square }\end{array}$} & \multirow{3}{*}{$\begin{array}{l}\text { Adjusted } \\
\text { R Square }\end{array}$} & \multirow{3}{*}{$\begin{array}{l}\text { Std. Error } \\
\text { of the } \\
\text { Estimate }\end{array}$} & \multicolumn{4}{|c|}{ Change Statistics } & \multirow{3}{*}{$\begin{array}{l}\text { Durbin- } \\
\text { Watson }\end{array}$} \\
\hline & & & & & $\mathrm{R}$ & $\mathrm{F}$ & df1 df2 & Sig. F & \\
\hline & & & & & $\begin{array}{l}\text { Square } \\
\text { Change }\end{array}$ & Change & & Change & \\
\hline 1 & .715 & .511 & .501 & 1.173 & .511 & 50.717 & 297 & .000 & 1.568 \\
\hline
\end{tabular}

a. Predictors: (Constant), Promosi, Kepercayaan

b. Dependent Variable: Minat Pembiayaan

Sumber: Data Primer diolah pada SPSS 21, 2020

\section{Pengaruh Kepercayaan terhadap Minat UMKM Mengambil Pembiayaan Perbankan Syariah di Kota Langsa}

Hasil penelitian menunjukkan bahwa kepercayaan berpengaruh positif signifikan terhadap minat UMKM mengambil pembiayaan perbankan syariah di Kota Langsa. Hal ini dibuktikan dengan hasil uji statistik diperoleh nilai sig sebesar 0,019. Berdasarkan ketentuannya jika nilai sig $<0,05(0,019<0,05)$ maka terdapat konstribusi yang signifikan kepercayaan terhadap minat UMKM mengambil pembiayaan perbankan syariah di Kota Langsa. Pengaruh positif signifikan menunjukkan bahwa variabel kepercayaan ini memiliki pengaruh yang besar terhadap minat UMKM mengambil pembiayaan. Sehingga semakin tinggi tingkat kepercayaan pelaku UMKM terhadap perbankan syariah maka akan memberikan dampak semakin tinggi pula minat UMKM mengambil pembiayaan di perbankan syariah.

Hal ini sesuai dengan teori yang dikemukakan oleh Morgan dan Hunt (1994) yang menjelaskan bahwa kepercayaan sebagai suatu kondisi ketika salah satu pihak yang terlibat dalam proses pertukaran yakin dengan keandalan dan integritas pihak yang lainnya. Sehingga semakin tinggi tingkat kepercayaan masyarakat terhadap perbankan syariah maka akan semakin tinggi minat masyarakat menggunakan jasa perbankan syariah.

\section{Pengaruh Promosi terhadap Minat UMKM Mengambil Pembiayaan Perbankan Syariah di Kota Langsa}

Hasil penelitian menunjukkan bahwa promosi berpengaruh positif signifikan terhadap minat UMKM mengambil pembiayaan perbankan syariah di Kota Langsa. Hal ini dibuktikan dengan hasil uji statistik diperoleh nilai sig sebesar 0,000. Berdasarkan ketentuannya jika nilai sig $<0,05(0,000<0,05)$ maka terdapat konstribusi yang signifikan promosi terhadap minat UMKM mengambil pembiayaan perbankan syariah di Kota Langsa. Pengaruh yang positif dan signifikan menunjukkan apabila semakin baik promosi yang dilaksanakan oleh 
pihak perbankan syariah maka semakin meningkatkan minat pelaku Usaha Mikro Kecil dan Menengah (UMKM) untuk mengambil pembiayaan di perbankan syariah.

Promosi merupakan kegiatan penting bagi setiap perusahaan termasuk bank karena sebaik apapun produk yang dihasilkan jika tidak dikenal oleh nasabah maka produk tersebut tidak akan berhasil di pasaran. Hal ini sesuai dengan teori dari Lamb, Hair dan Mc Daniel (2001) bahwa promosi merupakan komunikasi dari para penjual yang menginformasikan, membujuk dan mengingatkan para calon pembeli suatu produk dalam rangka mempengaruhi pandangan mereka atau memperoleh suatu tanggapan.

\section{KESIMPULAN}

Berdasarkan hasil penelitian dan pembahasan, maka dapat ditarik beberapa kesimpulan sebagai berikut.

1. Kepercayaan berpengaruh positif dan signifikan terhadap minat Usaha Mikro Kecil dan Menengah (UMKM) mengambil pembiayaan perbankan syariah di Kota Langsa. Hal ini dibuktikan dengan hail uji statistik nilai signifikansi 0,019 lebih kecil dari 0,05. Maka semakin tinggi tingkat kepercayaan pelaku usaha terhadap perbankan syariah maka minat mengambil pembiayaan perbankan syariah akan semakin meningkat.

2. Promosi berpengaruh positif dan signifikan terhadap minat Usaha Mikro Kecil dan Menengah (UMKM) mengambil pembiayaan perbankan syariah di Kota Langsa. Hal ini dibuktikan dengan hail uji statistik nilai signifikansi 0,000 lebih kecil dari 0,05. Semakin baik promosi yang dilakukan oleh pihak perbankan syariah maka semakin tinggi minat pelaku UMKM untuk mengambil pembiayaan di perbankan syariah.

3. Kepercayaan dan promosi secara bersama-sama berpengaruh positif dan signifikan terhadap minat Usaha Mikro Kecil dan Menengah (UMKM) mengambil pembiayaan perbankan syariah di Kota Langsa. Hal ini dibuktikan dengan hail uji statistik nilai signifikansi 0,000 lebih kecil dari 0,05. Artinya semakin meningkat kepercayaan dan promosi maka akan semakin meningkat minat pelaku Usaha Mikro Kecil dan Menengah (UMKM) untuk mengambil pembiayaan perbankan syariah di Kota Langsa.

\section{REFERENSI}

Adiyanto, Yoga, et. al, (2019). Bank dan Lembaga Keuangan Lainnya. Serang: Qiara Media. Antonio, Muhammad Syafii, (2001). Bank Syariah Dari Teori ke Praktek. Jakarta: Gema Insani.

Ascarya, (2013). Akad dan Produk Bank Syariah. Jakarta: Rajawali Pers. 
Budiarto,Rachmawan,et. al. (2015).Pengembangan UMKM Antara Konseptual dan Pengalaman Praktis. Yogyakarta: Gadjah Mada University Press

Bungin, Burhan.(2009). Metodelogi Penelitian Kuantitatif: Komunikasi, Ekonomi, Kebijakan Publik Serta Ilmu-Ilmu Sosial Lainnya. Jakarta: Kencana.

Danupranata, Gita, (2013). Buku Ajar Manajemen Perbankan Syariah. Jakarta: Salemba Empat.

Herjanto, Eddy. (2009). Sains Manajemen (Analisis Kuantitatif Untuk Pengambilan Keputusan). Jakarta: Grasindo.

Huda, Nurul dkk. (2017). Pemasaran Syariah: Teori dan Aplikasi. Bandung: Kencana.

Jogiyanto, (2007). Metodelogi Penelitian Bisnis:Salah Kaprah dan Pengalaman-Pengalaman. Yogyakarta: BPFE.

Juliandi, Azuar dan Irfan.(2013). Metodelogi Penelitian Kuantitati Untuk Ilmu-Ilmu Bisnis. Bandung: Citapustaka Media Perintis.

Kara, Muslimin. (2013). "Konstribusi Pembiayaan Perbankan Syariah Terhadap Pengembangan Usaha Mikro Kecil dan Menengah di Kota Makassar". Jurnal Ilmu Syariah dan Hukum, Vol. 47, No. 1.

Kismawadi, Early Ridho, Uun Dwi Al Muddatsir dan Abdul Hamid.(2020). Fraud Pada Lembaga Keuangan dan Nonkeuangan. Depok: PT Raja Grafindo Persada.

Kurniawan, Robert dan Budi Yuniarto. (2016). Analisis Regresi (Dasar dan Penerapannya Dengan R). Jakarta: Kencana.

Nugraha, Ch Asta, dkk. (2017). "Pengaruh Persepsi dan Nilai Nasabah Terhadap Tingkat Kepercayaan Bank" Jurnal Media Ekonomi dan Manajemen, Vol. 32, No. 1.

Sudarmanto, R. Gunawan. (2004). Analisis Regresi Linear Berganda Dengan SPSS. Bandung: Graha Ilmu.

Suhardi, Gunarto. (2006). "Faktor-Faktor Yang Mempengaruhi Kepercayaan dan Loyalitas Nasabah Perbankan di Surabaya”, Jurnal Kinerja. Vol. 10, No. 1.

Suryani dan Hendryadi, (2015). Metode Riset Kuantitatif: Teori dan Aplikasi Pada Penelitian Bidang Manajemen dan Ekonomi Islam. Jakarta: Prenamedia Group.

Utaminingsih, Alifiulahtin. (2014). Perilaku Organisasi Kajian Teoritik dan Empirik Terhadap Budaya Organisasi, Gaya Kepemimpinan, Kepercayaan dan Komitmen. Malang: Universitas Brawijaya Press, cet 1. 